J. Biosci., Vol. 6, Number 1, March 1984, pp. 61-67.

(C) Printed in India.

\title{
Water stress induced alterations in ornithine aminotransferase of ragi (Eleusine coracana): Protection by proline against heat inactivation and denaturation by urea and guanidinium chloride
}

\author{
RAJENDRA P. KANDPAL* and N. APPAJI RAO \\ Department of Biochemistry, Indian Institute of Science, Bangalore 560012, India \\ *Present address: Molecular Biology Institute, University of California, Los Angeles, \\ California 90024, USA \\ MS received 25 October 1983; revised 29 December 1983
}

\begin{abstract}
Water stress resulted in a specific response leading to a large and significant increase (80-fold) in free proline content of ragi (Eleusine coracana) leaves and seedlings. L-Proline protected ornithine aminotransferase, an enzyme in the pathway for proline biosynthesis, isolated from normal and stressed ragi leaves against heat inactivation and denaturation by urea and guanidinium chloride. The protection of the stressed enzyme by L-proline was much more complete than that of the enzyme isolated from normal leaves. While L-ornithine, one of the substrates, protected the stressed enzyme against inactivation, it enhanced the rate of inactivation of the normal enzyme. $\alpha$-Ketoglutarate protected both the normal and stressed enzyme against inactivation and denaturation. These results support the suggestion that ornithine aminotransferase has undergone a structural alteration during water stress. In view of the causal relationship between elevated temperature and water stress of plants under natural conditions, the protection afforded by proline against inactivation and denaturation of the enzyme from stressed leaves assumes significance. These results provide an explanation for a possible functional importance of proline accumulation during water stress.
\end{abstract}

Keywords. Ornithine aminotransferase; proline; water stress; Eleusine coracana.

\section{Introduction}

The most significant and easily detectable biochemical change when plants are deprived of water is the accumulation of free proline (Singh et al., 1972). In an earlier study, we showed that in polyethyleneglycol (PEG)-treated ragi (Eleusine coracana) leaves, the level of free proline increased by 85 -fold and this increase was probably due to an enhanced activity of the enzymes involved in the synthesis of proline and marked inhibition of the activity of enzymes degrading proline (Kandpal et al., 1981). The activity of ornithine aminotransferase (EC 2.6.1.13), an enzyme of proline biosynthesis, increased by about 3 fold in water-stressed ragi leaves. In a subsequent study, we showed that the increase in the activity of ornithine aminotransferase was not due to the presence of an activator but due to alteration in the properties of the enzyme isolated from water stressed leaves (Kandpal and Appaji Rao, 1982). The present study was undertaken to determine the differences between the enzyme isolated from normal and stressed leaves by using heat inactivation and denaturation by urea and guanidinium

Abbreviations used: PEG, Polyethyleneglycol (molecular weight 6000); GdmCl, guanidinium chloride. 
chloride $(\mathrm{GdmCl})$, as well as the effects of substrates and proline on inactivation patterns as probes for alterations in the structure of ornithine aminotransferase consequent to water stress.

\section{Materials and methods}

\section{Materials}

All biochemicals used in this study were obtained from the Sigma Chemicals Co., St. Louis, Missouri, USA. Polyethyleneglycol (6,000 molecular weight) was obtained from the SD's Lab Chem Industry, Bombay. All other chemicals and buffer components were of the reagent grade. Ragi (Eleusine coracana) seeds variety Purna were obtained from Dr. K. S. Krishnasastry, University of Agricultural Sciences, Bangalore.

\section{Methods}

Induction of water stress and purification of ornithine aminotransferase: Ragi seeds were grown in the Institute Nursery for a period of 30-45 days and young and fully expanded leaves were collected randomly and pooled for the isolation of the enzyme. In one set, the cut ends of the leaves were partly dipped in 40\% PEG and illuminated for 6-8 $\mathrm{h}$. The biochemical and physiological changes caused by PEG treatment were similar to natural water deprivation (Todd, 1972). It was also ascertained that in the ragi, proline accumulation, changes in enzyme activities RNA and DNA metabolism were similar in both PEG-treated and naturally water-stressed ragi leaves and seedlings (Kandpal, 1983). At the end of $8 \mathrm{~h}$, the leaves were washed free of PEG, blot-dried, cut into small pieces and stored frozen at $-20^{\circ} \mathrm{C}$. The normal leaves were similarly treated with water and processed. Acetone powder of the normal and PEG-treated leaves was prepared separately. The enzyme was partially purified from both the normal and stressed leaves and activity assayed as described earlier (Kandpal and Appaji Rao, 1982).

\section{Results}

Effect of substrates and proline on thermal stability of ornithine aminotransferase isolated from normal and stressed ragi (Eleusine coracana) leaves

It is evident from figure 1 that the normal enzyme retained about $40 \%$ of the original activity at the end of $30 \mathrm{~min}$ heating at $55^{\circ} \mathrm{C}$. The stressed enzyme, on the other hand, lost about $90 \%$ of its activity in this time interval. The stressed enzyme was protected to the extent of 20 and $30 \%$ respectively by L-ornithine $(12.0 \mathrm{mM})$ and $\alpha$-ketoglutarate $(15.0 \mathrm{mM})$. In the case of the normal enzyme, while $\alpha$-ketoglutarate offered significant protection $\left(t_{1 / 2}=20 \mathrm{~min}\right)$, L-ornithine enhanced $\left(t_{1 / 2}=4 \mathrm{~min}\right)$ its rate of inactivation 

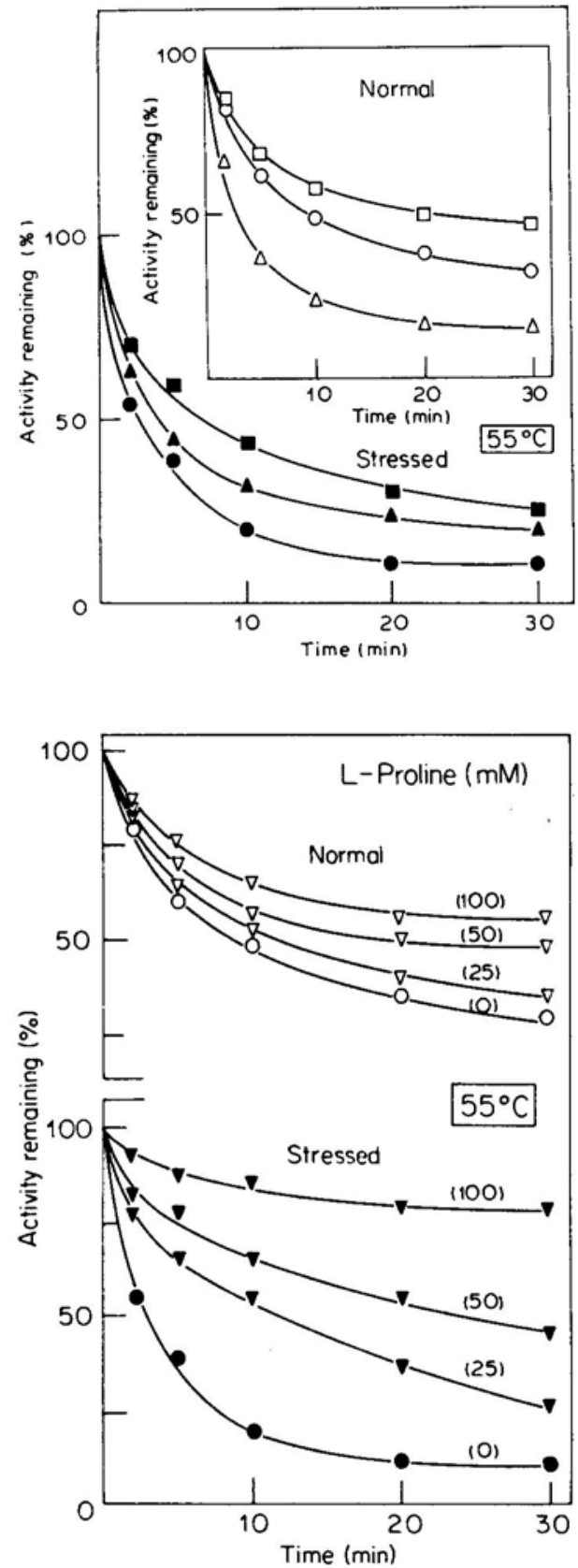

Figure 1. Heat inactivation patterns of the normal and stressed ornithine aminotransferase. The normal $(\mathrm{O})$ or stressed $(\bullet)$ enzymes $(5 \mathrm{mg} / \mathrm{ml})$ in $1 \mathrm{ml}$ of $0.1 \mathrm{M}$ potassium phosphate buffer $(\mathrm{pH} 8.0)$ were heated at $55^{\circ} \mathrm{C}$ in the absence of any of the substrates $(\mathrm{O}, \bullet)$ and in the presence of $12.0 \mathrm{mM}$ L-ornithine $(\Delta, \boldsymbol{\Delta})$ and $15.0 \mathrm{mM} \alpha$-ketoglutarate $(\square, \boldsymbol{\square})$. Aliquots of $0.1 \mathrm{ml}$ of the enzyme were withdrawn at time points indicated in the figure and rapidly cooled. The enzyme activity was assayed at $\mathrm{pH} 8.0$ and $37^{\circ} \mathrm{C}$ (Kandpal and Appaji Rao, 1982). The enzyme activity at zero time was normalized to 100 and the residual activity expressed as percent of this control.
Figure 2. Protection by L-proline against heat inactivation of the normal and stressed ornithine aminotransferase. The normal $(\mathrm{O})$ or stressed $(\bullet)$ enzymes $(5 \mathrm{mg} / \mathrm{ml})$ in $0 \cdot 1 \mathrm{M}$ potassium phosphate buffer $(\mathrm{pH} 8.0)$ were heated at $55^{\circ} \mathrm{C}$ in the absence $(\mathrm{O}, \bullet)$ and in the presence of $25 \mathrm{mM}, 50 \mathrm{mM}$ and $100 \mathrm{mM} \mathrm{L}$ proline $(\nabla, \boldsymbol{\nabla})$ Aliquots of $0.1 \mathrm{ml}$ were withdrawn at time points indicated in the figure and rapidly cooled. L-Proline $(100 \mathrm{mM})$ had no effect on the catalytic activity of either normal or stressed enzyme.

(figure 1). Proline protected the normal and stressed enzyme in a concentrationdependent manner, although the extent of protection was different (figure 2). At a maximal concentration of $100 \mathrm{mM}$, proline protected the normal enzyme only to $55 \%$ whereas the stressed enzyme was almost completely (80\%) protected against heat inactivation at $55^{\circ} \mathrm{C}$ for $30 \mathrm{~min}$ (figure 2). 
Effect of substrates and proline on urea and GdmCl denaturation of the enzyme isolated from normal and stressed ragi leaves

Although the denaturation patterns of the normal and stressed enzyme did not differ markedly in the absence of substrates, the differences were discernible when denaturation was carried out in the presence of substrates. While $\alpha$-ketoglutarate had comparable protective effect on the normal and stressed enzyme, L-ornithine enhanced the denaturation of the normal enzyme and protected the stressed enzyme by about $40 \%$ (figure 3 ).

The protection by proline against urea denaturation is shown in figure 4 . The effect of proline on urea denaturation patterns of the enzyme is similar to that against heat inactivation, although a higher concentration of proline was required for appreciable protection. At maximal concentration of proline $(200 \mathrm{mM})$, the normal and stressed enzyme retained 70 and $90 \%$ activity respectively (figure 4 ).

The enzymes from normal and stressed leaves were not inactivated at similar rates by $\mathrm{GdmCl}(0.5 \mathrm{M})$, the stressed enzyme being inactivated at a much faster rate. While Lornithine enhanced the rate of inactivation of the normal enzyme, it was without effect or provided marginal protection against inactivation of the stressed enzyme. The rates of denaturation of the normal and stressed enzyme in the presence of $\alpha$-ketoglutarate were similar (figure 5). The stressed enzyme which was being rapidly inactivated by $\mathrm{GdmCl}$, was very significantly protected by L-proline in a concentration-dependent manner. The effect of proline on the normal enzyme was similar but the extent of protection was not as marked (at $10 \mathrm{~min}$, the stressed enzyme in the presence of $100 \mathrm{mM}$ proline had $85 \%$ activity compared to $45 \%$ in the absence of proline, whereas the values for the normal enzyme were 80 and $65 \%$ respectively, figure 6).

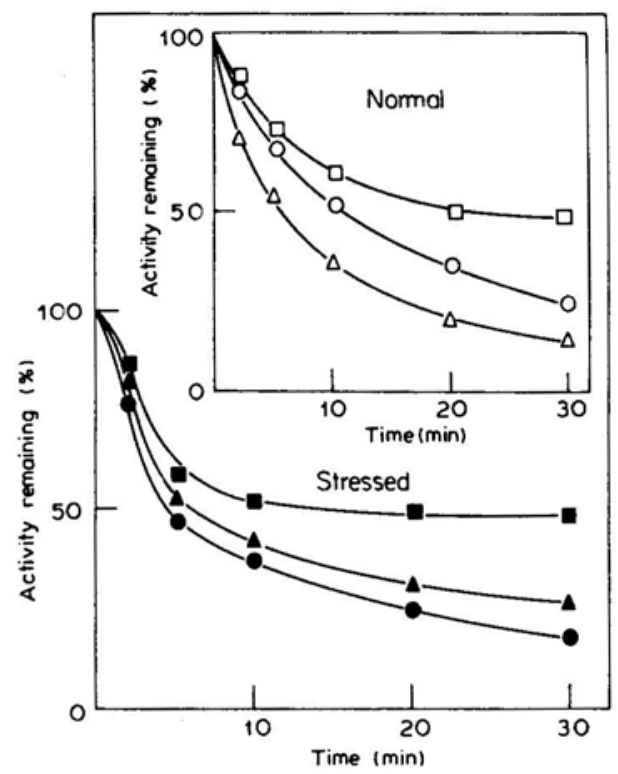

Figure 3. Urea denaturation patterns of normal and stressed ornithine aminotransferase. The normal $(\mathrm{O})$ or stressed $(\bullet)$ enzymes $(5 \mathrm{mg} / 0.5 \mathrm{ml}$ of buffer $\mathrm{pH} 8 \cdot 0)$ were incubated separately with $0.5 \mathrm{ml}$ of $2 \mathrm{M}$ urea solution $(\mathrm{pH} 8.0)$ at $37^{\circ} \mathrm{C}$ in the absence of any of the substrates $(\mathrm{O}, \bullet)$ and in the presence of $12.0 \mathrm{mM}$ L-ornithine $(\Delta, \boldsymbol{\Delta})$ and $15.0 \mathrm{mM} \alpha$ ketoglutarate $(\square, \boldsymbol{\square})$ Aliquots of $0 \cdot 1 \mathrm{ml}$ were withdrawn at time points indicated in the figure. 


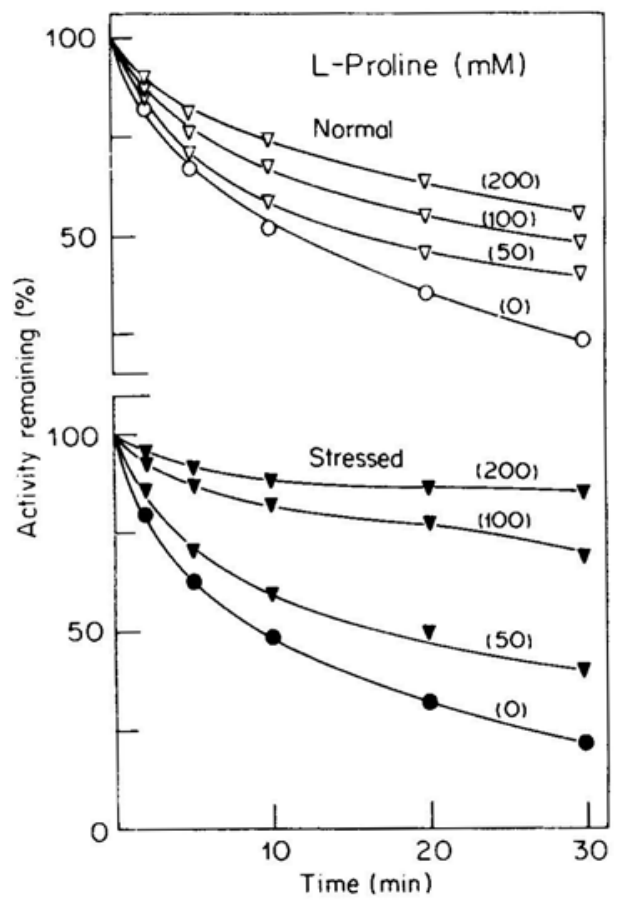

Figure 4. Protection by L-proline against urea denaturation of normal and stressed ornithine aminotransferase. The normal $(\mathrm{O})$ or stressed (๑) enzymes $(5 \mathrm{mg} / 0 \cdot 5 \mathrm{ml}$ of buffer $\mathrm{pH}$ 8.0) were incubated separately with $0.5 \mathrm{ml}$ of $2 \mathrm{M}$ urea solution $(\mathrm{pH} 8.0)$ at $37^{\circ} \mathrm{C}$ in the absence $(\mathrm{O}, \bullet)$ and in the presence of $50 \mathrm{mM}$, $100 \mathrm{mM}$ and $200 \mathrm{mM}$ proline $(\nabla, \boldsymbol{\nabla})$ Aliquots of $0.1 \mathrm{ml}$ were withdrawn at time points indicated in the figure.

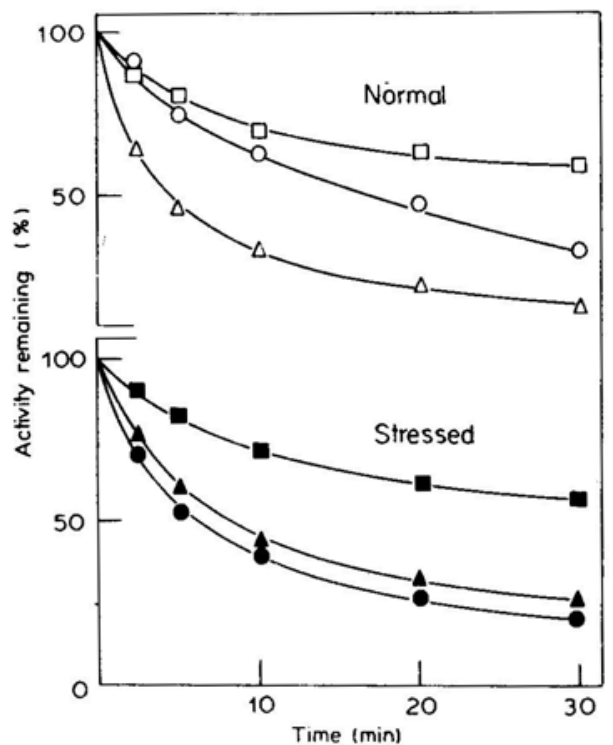

Figure 5. GdmCl denaturation patterns of normal and stressed ornithine aminotransferase. The normal $(\mathrm{O})$ or stressed $(\bullet)$ enzymes $(5 \mathrm{mg} / 0 \cdot 5 \mathrm{ml}$ of buffer) were incubated separately with $0.5 \mathrm{ml}$ of $1 \mathrm{M} \mathrm{GdmCl}$ at $37^{\circ} \mathrm{C}$ in the absence $(\mathrm{O}, \bullet)$ of any of the substrates and in the presence of $12.0 \mathrm{mM}$ L-ornithine $(\Delta, \boldsymbol{\Delta})$ and $15 \mathrm{mM} \alpha$-ketoglutarate $(\square, \boldsymbol{\square})$. Aliquots $(0 \cdot 1 \mathrm{ml})$ were withdrawn at time points indicated in the figure.

\section{Discussion}

The dramatic accumulation of proline in water-stressed plants has been ascribed to enhanced rate of synthesis due to increased activity of the enzymes involved in the biosynthesis and marked inhibition of the enzymes responsible for its degradation (Kandpal et al., 1981). Our earlier results showed that changes in the activity of ornithine aminotransferase were not due to the presence of a 'factor' which regulated its properties (Kandpal and Appaji Rao, 1982). Differential rates of inactivation by denaturing agents on interaction with small molecular weight ligands have been extensively used to indicate altered structures in protein molecules (Kaufman, 1968; Citri, 1973). Our results (figure 1) show that the stressed enzyme is more rapidly inactivated by heat compared to the enzyme from normal leaves. L-Ornithine, one of the substrates, protected the stressed enzyme while it enhanced the inactivation of the normal enzyme suggesting that water stress might have altered the structure of the 


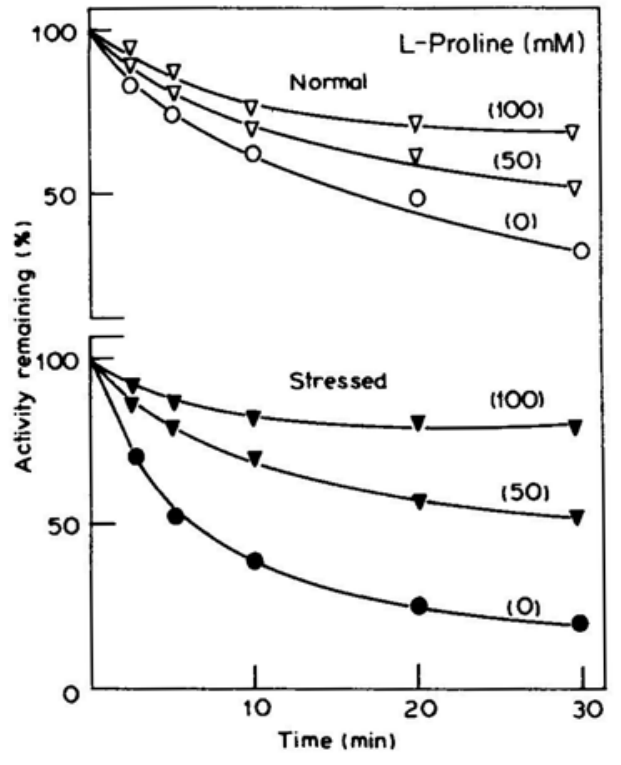

Figure 6. Protection by L-proline against $\mathrm{GdmCl}$ denaturation of normal and stressed ornithine aminotransferase. The normal $(\mathrm{O})$ or stressed(•) enzymes were incubated separately with $0.5 \mathrm{ml}$ of $\mathrm{GdmCl}$ at $37^{\circ} \mathrm{C}$ in the absence $(\mathrm{O}, \bullet)$ and presence of $50 \mathrm{mM}$ and $100 \mathrm{mM}$ praline $(\square, \boldsymbol{\square})$ Aliquots of $0.1 \mathrm{ml}$ were withdrawn at time points indicated in the figure.

enzyme. Similar denaturation profiles in the presence and absence of ligands were obtained when denaturation was carried out at $50^{\circ}$ and $60^{\circ} \mathrm{C}$ (data not given). Further support to this hypothesis is lent by urea and $\mathrm{GdmCl}$ denaturation patterns of the normal and stressed enzyme in presence of L-ornithine (figures 3 and 5).

In view of the large accumulation of proline during stress (Chu et al., 1978; Hellebust, 1976), and the effects of proline on protein structure due to its hydrogen bonding capacity and interactions with hydrophobic regions in the protein (Schobert, 1977; Schobert and Tschesche, 1978) it was of interest to examine the effect of proline on an enzyme involved in its biosynthesis. As high as $200 \mathrm{mM}$ concentration of L-proline had no stimulatory or inhibitory effect on the enzyme activity. It is significant that although proline afforded some protection to the normal enzyme, it almost completely protected the stressed enzyme against heat inactivation and urea and $\mathrm{GdmCl}$ denaturation. This is especially pertinent as elevation in temperature occurs during water stress which may result in inactivation of enzymes (Smith, 1978). The stressed enzyme which encounters high temperature is also protected by proline which accumulates during water stress. It has been calculated that the concentration of proline in stressed tissue varies between 100 and $200 \mathrm{mM}$.

It could be suggested from these observations that inhibition of the degradation of proline during water stress (Kandpal et al., 1981) resulted in its accumulation, which in turn by its protective effects on the enzymes involved in its biosynthesis further facilitated marked accumulation of proline. These effects of proline provide clues to the possible role it may have in the adaptation of some plants to intermittent stress to which they are subjected when grown in the tropics. 


\section{Acknowledgements}

We are thankful to the Indian Council of Agricultural Research, Government of India, for financial support. R.P.K. was the recipient of a Senior Research Fellowship of the Department of Atomic Energy, Government of India.

\section{References}

Citri, N. (1973) Adv. Enzymol., 37, 397.

Chu, T. M., Jusaitis, M., Aspinall, D. and Paleg, L. G. (1978) Physiol. Plant., 43, 254.

Hellebust, J. A. (1976) Ann. Rev. Plant Physiol., 27, 485.

Kandpal, R. P., Vaidyanathan, C. S., Udaya Kumar, M., Krishnasastry, K. S. and Appaji Rao, N. (1981) J. Biosci., 3, 361.

Kandpal, R. P. and Appaji Rao, N. (1982) Biochem. Int., 5, 297.

Kandpal, R. P. (1983) Biochemical Mechanisms of Adaptation to Water Stress in Ragi (Eleusine coracana), Ph.D Thesis, Indian Institute of Science, Bangalore.

Kaufman, B. T. (1968) J. Biol. Chem., 243, 6001.

Schobert, B. (1977) J. Theor. Biol., 68, 17.

Schobert, B. and Tschesche, H. (1978) Biochim. Biophys. Acta, 541, 270.

Singh, T. N., Aspinall, D. and Paleg, L. G. (1972) Nature (London), 236, 188.

Smith, W. K. (1978) Science, 201, 614.

Todd, G. W. (1972) in Water Deficits and Plant Growth III, ed. T. T. Kozlowski, (New York: Academic Press) P 177. 